\title{
VALIDITAS INSTRUMEN TES BERPIKIR TINGKAT TINGGI (HOTS) PADA MATERI SISTEM RESPIRASI DI KELAS XI SMA
}

\author{
Marvia Afrita ${ }^{*}$, Rahmawati Darussyamsu \\ Program Studi Pendidikan Biologi Fakultas Matematika dan Ilmu Pengetahuan Alam \\ Universitas Negeri Padang \\ Jl. Prof. Dr. Hamka Air Tawar Padang, Indonesia \\ ${ }^{*}$ Email: marviaafrita98@gmail.com
}

Doi: https://doi.org/10.31943/mangiferaeduv4i2.83

Received: 26 Desember 2019 Accepted: 29 Januari 2020 Published: 31 Januari 2020 Citasi: Afrita, M., Rahmawati, D. 2019. Validitas Instrumen Penilaian Kemampuan Berpikir Tingkat Tinggi Materi Sistem Respirasi Peserta Didik SMA/MA Kelas XI. Jurnal Mangifera Edu. 4(2), 129-142.

\begin{abstract}
Higher order thinking skills is very important in the 2013 curriculum. This 2013 curriculum emphasizes the ability of reasoning for concepts. This ability involves a high cognitive level from Bloom's taxonomy, C4-C6. One example in improving students HOTS is to develop assessment instruments HOTS. This type research is research and development $(R \& D)$ research with using the $4 D$ models. This research develop an assessment instrument in the form of multiple choice. In this research, the object is assessment instrument HOTS on respiration system content. The subject of this research were two lectures major in Biology, Faculty of Mathematics and Natural Sciences UNP. The result of validation show an average value of 87.91 with a valid category. This shows of assessment instrument HOTS on respiration system content is valid among in terms of the feasibility aspects of content, construction, language, and the cognitive level of the assessment instruments is at a HOTS.
\end{abstract}

Keywords: Validity, HOTS, Respiration System

\section{ABSTRAK}

Kemampuan berpikir tingkat tinggi penting dalam kurikulum 2013. Kurikulum 2013 ini menekankan pada kemampuan penalaran atas konsep-konsep. Kemampuan ini melibatkan tingkatan kognitif tinggi dari taksonomi Bloom yaitu $C_{4}-C_{6}$. Satu contoh dalam meningkatkan kemampuan berpikir tingkat tinggi peserta didik dikembangkanlah instrumen penilaian kemampuan berpikir tingkat tinggi. Jenis penelitian adalah penelitian pengembangan dengan model 4D. Penelitian ini mengembangkan instrumen penilaian dalam bentuk pilihan ganda. Objek penelitian ini adalah instrumen penilaian kemampuan berpikir tingkat tinggi pada materi sistem respirasi. Subjek penelitian ini adalah dua orang dosen jurusan Biologi FMIPA UNP. Hasil validasi menunjukkan nilai rata-rata $87,91 \%$ dengan kriteria valid yang diperoleh dari analisis statistik deskriptif menggunakan microsoft excel untuk menganalisis data dari hasil angket validasi yang di isi validator. Ini menunjukkan instrumen penilaian kemampuan berpikir tingkat tinggi pada materi sitem respirasi valid dikembangkan dari segi aspek materi, kontruksi, bahasa dan tingkat kognitif 
instrumen penilaian berada pada tingkatan kemampuan berpikir tingkat tinggi yang mengidentifikasikan bahwa instrumen ini dapat digunakan untuk mengukur kemampuan berpikir tingkat tinggi peserta didik pada materi sistem respirasi.

Kata Kunci: Validitas, HOTS, Sistem Respirasi

\section{PENDAHULUAN}

Kemampuan berpikir tingkat tinggi (High Order Thinking Skill/HOTS) ditekankan dalam pembelajaran kurikulum 2013. Kemampuan berpikir tingkat tinggi sebagai salah satu aspek penting dalam pendidikan (Karim \& Marzita, 2019). Kemampuan ini sangat penting dalam proses pendidikan karena dapat mempengaruhi kemampuan peserta didik (Ramdiah dkk, 2019). HOTS tidak hanya berpikir mengingat dan menerapkan melainkan kemampuan berpikir tingkat tinggi meliputi aspek kemampuan berpikir kritis, logis, reflektif, metakognitif, dan kreatif (Amin \& Darsono, 2018). Sejalan dengan Hamdi dkk (2018), HOTS termasuk pemikiran kritis, kreatif, dan pemecahan masalah. HOTS juga menuntut peserta didik untuk mencapai kemungkinan jawaban dalam situasi baru (Kusuma dkk, 2017). HOTS didefenisikan sebagai penggunaan kemampuan berpikir lebih luas dalam pemecahan masalah yang rumit atau menemukan tantangan baru (Kodriana, et al, 2017). HOTS dapat dilatih dalam kegiatan pembelajaran (Kurniawan, 2018). Keterampilan berpikir tingkat tinggi ini sebagai kegiatan berpikir yang melibatkan level kognitif hirarki tinggi dari taksonomi berpikir Bloom.

Forehand (2011) menyatakan bahwa taksonomi Bloom memunculkan banyak istilah dalam pendidikan seperti high and low level thinking. Krathwohl (2002) merevisi taksonomi ini dengan mengklasifikasikan enam proses kognitif mulai dari jenjang proses berpikir terendah sampai tertinggi yaitu mengingat (C1), memahami (C2), mengaplikasikan (C3), menganalisis (C4), mengevaluasi (C5) dan kreasi atau mencipta (C6). Terdapat dua level berpikir siswa, yakni Low Order Thinking (C1-C3) dan High Order Thinking (C4-C6). Kemampuan menganalisis, mengevaluasi, dan mencipta merupakan kemampuan yang harus dikembangkan siswa agar dapat berpikir tingkat tinggi.

Rahmawati (2016) dalam seminar hasil TIMSS 2015, mengungkapkan bahwa siswa Indonesia perlu penguatan kemampuan mengintegrasikan informasi, menarik kesimpulan, serta menggeneralisir pengetahuan yang dimiliki ke hal-hal lain. Indonesia sudah berpartisipasi pada studi TIMSS sejak tahun 1999, namun capaian siswa di Indonesia masih dikategorikan rendah jika dibandingkan dengan negara lain dan tidak mengalami 
peningkatan yang berarti. Hasil studi TIMSS 2003, pencapaian siswa Indonesia berada pada posisi 35 dari 46 negara peserta dengan rata-rata skor 411, sedangkan rata-rata skor internasional yaitu 467. Pada hasil studi TIMSS 2007 pencapaian siswa Indonesia berada pada posisi 36 dari 49 negara peserta dengan rata-rata skor 397, sedangkan rata-rata skor internasional yaitu 500. Tahun 2011, Indonesia berada pada posisi 38 dari 42 negara peserta dengan rata-rata skor, 386 sedangkan rata-rata skor internasional 500. Pada tahun 2015, Indonesia berada pada posisi ke 44 dari 49 negara peserta dengan hasil rata-rata skor 397, sedangkan rata-rata skor internasional ialah 500 (Hadi dan Novaliyosi, 2019: 563).

Berdasarkan hasil wawancara yang telah dilakukan pada tanggal 9 Maret 2019 dengan salah satu guru Biologi di SMAN 4 Pariaman, mengatakan bahwa adanya evaluasi yang dilakukan sekolah baik ketika ulangan harian, ujian tengah semester, dan ujian semester yang dilaksanakan dalam bentuk tes pilihan ganda dan essay. Evaluasi ini digunakan sebagai tolok ukur kemampuan siswa. Tes yang dibuat berada pada tingkatan kognitif C1-C6. Namun, guru mengalami kesulitan dalam pembuatan soal-soal dengan tingkatan C4-C6. Hal ini sejalan dengan pendapat Arifin (2018) bahwa guru terbiasa memberikan soal yang hanya mengukur tingkat kemampuan dasar. Soal-soal latihanyang terdapat pada buku biologi masih pada tingkatan low order thinking (Zehlia et al., 2019).

Berdasarkan hasil analisis instrumen ujian tengah semester ganjil tahun pelajaran 2018/2019 di SMAN 4 Pariaman, didapatkan pada instrumen tersebut didominasi oleh soal dengan tingkat kognitif C1-C3. Persentase tingkatan kognitif pada instrumen ujian tengah semester pada tingkatan C1 sebanyak 14,28\%, C2 sebanyak 62,85\%, C3 sebanyak 20\%, C4 sebanyak 2,85\%, C5 dan C6 sebanyak 0\%. Hasil analisis instrumen ujian tengah semester ini dapat membuktikan bahwa tingkatan C1 sampai C3 mendominasi dengan persentase 97,14\% sedangkan tingkatan C4 sampai C6 jarang digunakan dengan persentase hanya $2,85 \%$.

Berdasarkan hasil uji coba tes instrumen pada siswa kelas XI IPA 2 SMAN 4 Pariaman, dengan menggunakan soal Haryanto (2018) pada materi Fungi yang telah valid dan praktis, diketahui bahwa kemampuan berpikir tingkat tinggi pada siswa kelas XI IPA 2 memiliki hasil rata-rata nilai sebesar 25,07. Artinya kemampuan berpikir tingkat tinggi siswa tersebut termasuk kategori rendah.

Instrumen penilaian kemampuan berpikir tingkat tinggi dapat mengasah penalaran siswa sehingga mampu meningkatkan kemampuan berpikir tingkat tinggi. Sistem respirasi sebagai salah satu materi pokok pada kompetensi dasar tuntutan kurikulum 2013 yang terdapat di Permendikbud nomor 37 tahun 2018, sistem respirasi merupakan materi KD 3.8 
pada kelas XI SMA/MA. Kompetensi dasar tersebut menuntut siswa mampu menganalisis hubungan antara struktur jaringan penyusun organ pada sistem respirasi dan mengaitkannya dengan bioprosesnya sehingga dapat menjelaskan proses pernapasan serta gangguan fungsi yang mungkin terjadi pada sistem respirasi manusia.

Berdasarkan analisis instrumen penilaian ulangan harian, menunjukkan belum tersedianya instrumen penilaian kemampuan berpikir tingkat tinggi pada materi sistem respirasi. Dengan demikian, instrumen penilaian tersebut dapat dikembangkan dengan mengacu pada soal-soal berpikir tingkat tinggi. Instrument berpikir tingkat tinggi pada sistem respirasi nantinya dapat digunakan untuk ulangan harian, ujian tengah semester, maupun ujian semester.

Instrumen penilaian kemampuan berpikir tingkat tinggi harus memperhatikan kompetensi yang dinilai, kontruksi dengan rumusan yang jelas, bahasa yang sesuai dengan kaidah yang berlaku dan tingkatan kognitif yang sesuai dalam kemampuan berpikir tingkat tinggi. Aspek ini dapat diperoleh dengan adanya validitas yang dilakukan terhadap instrumen penilaian yang dibuat sehingga instrumen penilaian yang dikembangkan valid untuk digunakan.

\section{METODOLOGI PENELITIAN}

Jenis penelitian ini adalah penelitian pengembangan (development research) dengan menggunakan model 4-D (four-D models). Penelitian ini bertujuan untuk mengetahui validitas instrumen penilaian kemampuan berpikir tingkat tinggi materi sistem respirasi untuk siswa kelas XI SMA/MA. Penelitian ini dilakukan di Fakultas Matematika dan Ilmu Pengetahuan Alam (FMIPA) Universitas Negeri Padang (UNP) dan SMAN 4 Pariaman. Penelitian dilaksanakan pada bulan November 2019. Validator instrument sebanyak dua orang yaitu dosen Jurusan Biologi FMIPA UNP dan 25 orang siswa SMAN 4 Pariaman.

Instrumen penilaian kemampuan berpikir tingkat tinggi ini dikembangkan dengan tahapan yaitu, pendefinisian (define), perancangan (design), pengembangan (develop), dan penyebaran (disseminate) (Rochmad, 2012). Pada penelitian ini dilakukan sampai tahap pengembangan, sedangkan tahap penyebaran tidak dilakukan karena keterbatasan waktu dan biaya.

Teknik pengumpulan data yang digunakan adalah analisis statistik deskriptif. Analisis data digunakan untuk mengolah data dari hasil validasi ahli mengenai materi, kontruksi, bahasa, dan kemampuan berpikir tingkat tinggi berupa masukan saran serta 
kritik perbaikan yang terdapat pada angket instrumen validasi. Analisis statistik deskriptif menggunakan microsoft excel untuk menganalisis data yang diperoleh dari hasil angket validasi yang diisi oleh validator dari segi materi, kontruksi, bahasa, dan kemampuan berpikir tingkat tinggi dengan validator dosen biologi yang berpengalaman dalam mengajar pokok bahasan sistem respirasi dan hasil angket validasi diolah dalam bentuk analisis persentase.

\section{HASIL DAN PEMBAHASAN}

Langkah dalam pembuatan instrumen ini terdiri dari tahap define, design, dan develop (Rochmad, 2012). Pada tahapan define dalam pengembangan instrumen penilaian kemampuan berpikir tingkat tinggi, peneliti melakukan analisis masalah yang terdapat di sekolah. Pada tahapan design penelitian ini, peneliti melakukan perancangan instrumen penilaian kemampuan berpikir tingkat tinggi pada materi sistem respirasi. Pada tahap ketiga yaitu tahap develop atau tahap pengembangan. Tahapan ini meliputi validasi oleh pakar atau ahli.

Tahap Define (Pendefenisian)

Hasil tahapan define di SMAN 4 Pariaman dengan melakukan analisis masalah yaitu pada tingkat kognitif instrumen penilaian ujian tengah semester ganjil tahun pelajaran 2018/2019, didapatkan instrumen penilaian tengah semester dalam bentuk pilihan ganda 30 pertanyaan dan essay 5 pertanyaan yang diujikan pada siswa masih dominan dalam tingkatan kognitif $\mathrm{C}_{1}-\mathrm{C}_{3}$, dengan persentase tingkatan kognitif $\mathrm{C}_{1} 14.28 \%, \mathrm{C}_{2} 62.85 \%, \mathrm{C}_{3}$ $20 \%, \mathrm{C}_{4} 2.85 \%, \mathrm{C}_{5}$ dan $\mathrm{C}_{6} 0 \%$. Arti \& Hariyatmi (2015) tingkatan kognitif terdiri dari dua level yaitu berpikir tingkat tinggi (HOTS) dan berpikir tingkat rendah (LOTS). Pada tingkatan level LOTS terdiri atas tingkatan kognitif $\mathrm{C}_{1}$ (mengingat), $\mathrm{C}_{2}$ (memahami), dan $\mathrm{C}_{3}$ (menerapkan). Sedangkan, tingkatan level HOTS terdiri atas tingkatan kognitif $\mathrm{C}_{4}$ (menganalisis), $\mathrm{C}_{5}$ (menilai), dan $\mathrm{C}_{6}$ (mencipta). Persentase tingkatan kognitif pada instrumen penilaian ujian tengah semester yaitu, tingkatan kognitif $C_{1}$ sebanyak 14,28\%, tingkatan kognitif $\mathrm{C}_{2}$ sebanyak $62,85 \%$, tingkatan kognitif $\mathrm{C}_{3}$ sebanyak $20 \%$, tingkatan kognitif $\mathrm{C}_{4}$ sebanyak 2,85\%, tingkatan kognitif $\mathrm{C}_{5}$ dan $\mathrm{C}_{6}$ sebanyak $0 \%$. Dari hasil ini, instrumen penilaian ujian tengah semester masih dalam tingkatan kognitif berpikir tingkat rendah.

Analisis terhadap siswa yang dilakukan peneliti melalui observasi diketahui umumnya siswa yang duduk di kelas XI berusia 17-18 tahun. Usia ini seharusnya telah mampu mengembangkan kemampuan berpikir tingkat tinggi dan menemukan tantangan 
dalam berpikir. Rofiah dkk (2013) kemampuan berpikir tingkat tinggi sebagai kemampuan untuk menentukan tantangan baru. Teori belajar Piaget, usia anak 12 sampai 18 tahun sudah memasuki tahap operasional formal, ciri pokok perkembangannya sudah mampu berpikir abstrak dan logis, mampu menarik kesimpulan, menafsirkan dan mengembangkan hipotesa (Berk, 2006). Pencapaian kompetensi kognitif siswa dapat dilihat dengan memberikan suatu tes atau instrumen penilaian (Sulistyorini, dkk, 2013). Analisis kemampuan berpikir tingkat tinggi siswa yang dilakukan peneliti juga menunjukkan masih rendahnya kemampuan siswa dalam menjawab soal-soal berpikir tingkat tinggi pada materi fungi. Hal ini dikarenakan siswa belum terlatih dalam menjawab soal-soal dengan tingkatan kognitif $\mathrm{C}_{4}-\mathrm{C}_{6}$ sesuai dari hasil wawancara dengan siswa dan analisis instrumen penilaian yang ada pada sekolah.

Analisis kurikulum lebih difokuskan pada Kompetensi Dasar (KD) sebagai target spesifik dari Kompetensi Inti (KI) yang dijabarkan untuk mencapai indikator (Herlanti, 2015). Analisis KI dan KD pada materi sistem respirasi mengacu pada Kurikulum 2013 Revisi 2016. Instrumen penilaian ini dibuat pada materi sistem respirasi dikarenakan belum tersedianya instrumen penilaian berpikir tingkat tinggi pada materi tersebut dilihat dari tingkatan kognitif instrumen penilaian ulangan harian materi sistem respirasi dengan tingkatan kognitif $\mathrm{C}_{1} 40 \%, \mathrm{C}_{2} 50 \%$ dan $\mathrm{C}_{3} 10 \%$.

Analisis konsep dilakukan dengan mengidentifikasi konsep-konsep utama dari materi sistem respirasi. Febriyanto et al (2018), konsep sebagai bagian dari materi pemebelajaran dalam perkembangan intelektual siswa. Konsep utama pada materi sistem respirasi terkait dengan indikator pencapaian kompetensi yaitu mengenai struktur jaringan penyusun organ sistem respirasi manusia, organ sistem respirasi manusia, bioproses pernapasan pada sistem respirasi manusia, dan gangguan fungsi pada sistem respirasi manusia. Organ sistem respirasi manusia seperti hidung, faring, laring, trakea, bronkus, paru-paru. Proses pernapasan pada manusia terdiri dari pernapasan dada dan pernapasan perut. Udara pernapasan pada manusia seperti udara tidal, udara cadangan, udara residu, udara komplementer. Peneliti menyusun konsep-konsep utama materi agar instrumen HOTS yang dikembangkan sesuai dengan materi yang dipelajari oleh peserta didik dan tuntutan kurikulum 2013.

\section{Tahap Perancangan (Design)}

Hasil Perancangan instrumen penilaian kemampuan berpikir tingkat tinggi pada materi sistem respirasi ini ialah kisi-kisi soal dengan memilih stimulus yang menarik dan 
kontekstual, menulis butir soal yang sesuai dengan kisi-kisi soal, dan membuat kunci jawaban. Menurut Susiatin (2019) kisi-kisi soal dibuat dengan baik sehingga soal yang dihasilkan dari kisi-kisi berkualitas. Perancangan kisi-kisi instrumen kemampuan berpikir tingkat tinggi ini dibuat berdasarkan indikator pencapaian kompetensi yang telah dikembangkan, serta menggunakan stimulus, tabel, wacana, diagram, dan gambar.

Instrumen penilaian kemampuan berpikir tingkat tinggi dirancang berdasarkan kisikisi instrumen penilaian kemampuan berpikir tingkat tinggi yang telah dibuat. Rancangan awal pembuatan soal ini dihasilkan 50 butir soal. Pada penelitian ini, peneliti mengembangkan instrumen penilaian dalam bentuk pilihan ganda dengan lima pilihan jawaban. Zainab \& Wilujeng (2016) instrumen penilaian pilihan ganda dapat mengukur kognitif produk serta mengetahui kemampuan peserta didik secara utuh. Bentuk tes pilihan ganda juga dapat mengukur penguasaan peserta didik terhadap pokok bahasan (Samritin \& Suryanto, 2016). Soal pilihan ganda terdiri dari pokok soal dan pilihan jawaban dengan penilaiannya dapat diskor dengan mudah, cepat, dan memiliki objektivitas tinggi walaupun pilihan ganda yang bermutu perlu waktu dalam penyusunan soal (Marhamah, 2019). Bentuk pilihan ganda pada instrumen penilaian kemampuan berpikir tingkat tinggi juga dapat mengukur pola distribusi jawaban.

Kunandar (2015), pola distribusi jawaban menggambarkan bagaimana peserta tes menentukan pilihan jawaban terhadap kemungkinan-kemungkinan jawaban yang telah dipasangkan pada setiap butir soal pada instrumen penilaian. Soal yang dirancang terdiri dari 35 butir soal pilihan ganda biasa, 7 butir soal asosiasi pilihan ganda, dan 8 butir soal sebab akibat. Butir soal yang dirancang berada pada tingkatan kognitif $\mathrm{C}_{4}$ sampai $\mathrm{C}_{6}$. Tingkatan kognitif C4 sebanyak 35 soal, C5 14 soal dan C6 1 soal. Soal tersebut dilengkapi dengan gambar, grafik, tabel, wacana yang berfungsi sebagai stimulus. Jenis tulisan yang digunakan untuk merancang instrumen penilaian kemampuan berpikir tingkat tinggi ini adalah Times New Roman dengan ukuran huruf 12 pt.

Hasil perancangan lainnya yang dilakukan peneliti ialah adanya kunci jawaban sebagai alat yang dapat digunakan untuk pemeriksaan lembar jawaban peserta didik terhadap instrumen penilaian kemampuan berpikir tingkat tinggi. Peneliti juga merancang sampul (cover) instrumen penilaian kemampuan berpikir tingkat tinggi terdiri dari judul, logo Tut Wuri Handayani, logo Kurikulum 2013, nama pembimbing, nama validator, dan nama penyusun. Bagian sampul dirancang dengan dominasi warna biru yang dilengkapi dengan gambar organ sistem respirasi pada manusia. 


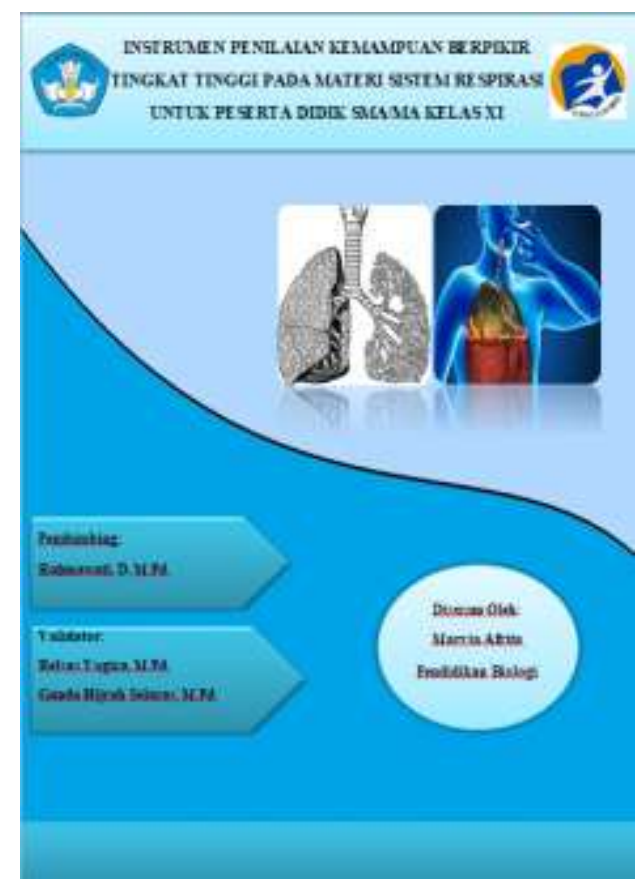

\section{Gambar 1. Sampul Instrumen Penilaian HOTS Materi Sistem Respirasi}

Peneliti juga merancang petunjuk pengerjaan instrumen penilaian yang berisi pedoman dan aturan untuk mengerjakan instrumen penilaian kemampuan berpikir tingkat tinggi. Depdiknas (2008), salah satu langkah dalam perakitan soal adanya petunjuk untuk mengerjakan instrumen penilaian. Petunjuk ini terdiri dari petunjuk umum dan petunjuk khusus. Petunjuk umum yang digunakan sama seperti petunjuk pengerjaan soal secara umum, yaitu memuat waktu pengerjaan, jumlah soal yang diberikan, dan peraturan umum lainnya. Petunjuk khusus terdiri dari jenis bentuk soal yang diberikan, yaitu bentuk pilihan ganda biasa, pilihan ganda asosiasi, dan pilihan ganda sebab akibat. Petunjuk pengerjaan instrumen ini ditulis dengan menggunakan jenis huruf Times New Roman dengan ukuran huruf $12 \mathrm{pt}$.

\section{Tahap Pengembangan (Develop)}

Tahap ini meliputi validasi instrumen penilaian kemampuan berpikir tingkat tinggi. Validasi digunakan untuk menentukan tingkat kelayakan suatu tes (Erfienti dkk, 2019). Validasi instrumen penilaian kemampuan berpikir tingkat tinggi dilakukan oleh dua orang dosen jurusan Biologi FMIPA UNP dengan menggunakan angket validasi. Angket validitas penilaian ahli tersebut berkategori validitas valid atau tidak dapat ditinjau dari segi materi, konstruksi, atau bahasa (Gonibala dkk, 2019). Pada penelitian ini juga ditinjau dari aspek kemampuan berpikir tingkat tinggi. Pada aspek ini, validator memberikan penilaian pada angket validasi mengenai instrumen penilaian yang dibuat dengan indikator 
berupa soal-soal berstimulus menarik dengan tingkatan kognitif menganalisis, mengevaluasi, dan mencipta. Istilah valid dikenal sebagai alat evaluasi atau instrumen evaluasi (Arikunto, 2016). Validasi yang dilakukan terhadap instrumen penilaian kemampuan berpikir tingkat tinggi menggunakan angket validasi di isi oleh dua orang validator. Hasil validasi ini dapat dilihat pada Gambar 1.

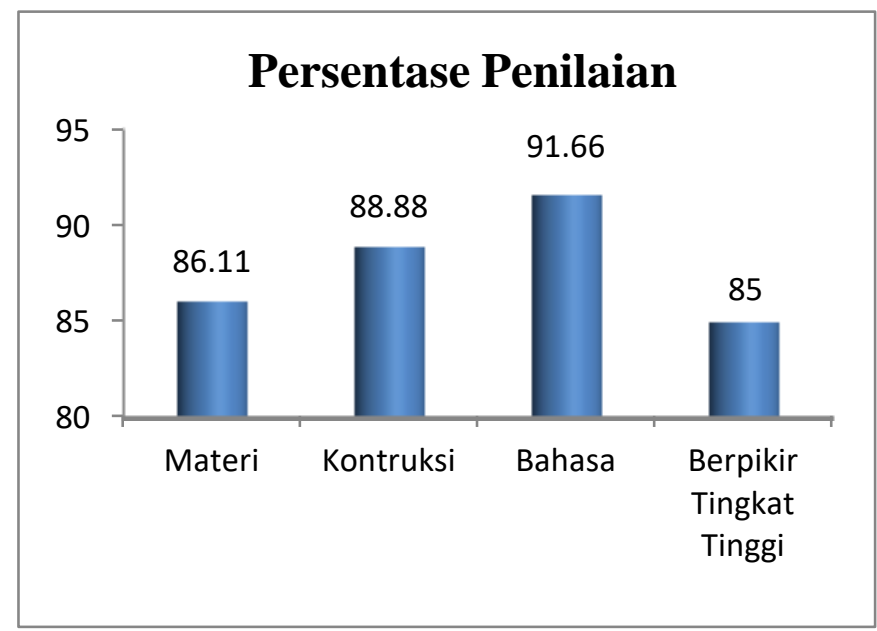

\section{Gambar 2. Hasil Pesentase Rata-rata Penilaian Dua Validator}

Hasil validasi pada Gambar 1 menunjukkan nilai persentase rata-rata semua aspek dari dua orang validator ialah $87,91 \%$ dengan kategori valid. Butir soal dengan kualitas baik memiliki validitas baik dengan penilaian yang tinggi atau valid (Susanty, 2016). Nilai persentase rata-rata menunjukkan bahwa instrumen penilaian kemampuan berpikir tingkat tinggi yang dikembangkan valid baik dari segi aspek materi, kontruksi, bahasa, dan instrumen penilaian berpikir tingkat tinggi. Dalam pengembangannya, instrumen penilaian kemampuan berpikir tingkat tinggi ini telah mengalami revisi berdasarkan saran-saran yang diberikan validator. Saran validator terhadap instrumen kemampuan berpikir tingkat tinggi seperti pada aspek materi dilakukan dengan memperbaiki gambar dan menggantinya dengan kualitas gambar bagus. Dalam aspek bahasa, saran validator yaitu memperbaiki susunan kalimat pada beberapa soal, memperbaiki dan menghilangkan pernyataan soal yang tidak diperlukan.

Berdasarkan hasil dari analisis data yang dilakukan maka hasil uji validitas instrumen penilaian kemampuan berpikir tingkat tinggi pada materi sistem respirasi oleh dosen ditinjau dari segi materi yang dikembangkan tergolong valid dengan nilai $86.11 \%$. Aspek materi ini berkaitan dalam keilmuan dan tingkat berpikir pada butir soal yang telah dibuat (Munadi, 2011). Nilai persentase yang diperoleh berarti instrumen penilaian kemampuan berpikir tingkat tinggi yang dikembangkan telah sesuai dengan Kompetensi 
Inti dan Kompetensi Dasar. Hal ini sesuai dengan Depdiknas (2017) menyatakan bahwa materi yang dikembangkan harus sesuai dengan Kompetensi Dasar dan Indikator.

Pada aspek konstruksi instrumen penilaian kemampuan berpikir tingkat tinggi materi sistem respirasi dinyatakan valid dengan nilai $88.88 \%$. Aspek kontruksi yang dinilai ini berguna untuk peningkatan mutu soal dari penulisan soal serta jawaban (Ariningrum, 2016). Berdasarkan hasil validitas, hal ini yang menunjukkan bahwa instrumen penilaian kemampuan berpikir tingkat tinggi yang digunakan menggunakan kontruksi soal dengan rumusan yang jelas. Sejalan dengan pernyataan Depdiknas (2017) bahwa pokok soal dirumuskan dengan singkat, jelas, dan tegas. Aspek kontruksi ini, pokok soal tidak memberi petunjuk kunci jawaban dan tidak menggunakan pernyataan negatif ganda, serta butir soal tidak bergantung pada jawaban soal sebelumnya. Menurut Kadir (2015), butir soal dengan kontruksi baik apabila pokok soal dirumuskan dengan jelas yang mencakup pernyaataan yang diperlukan saja.

Pada tinjauan aspek bahasa, instrumen penilaian kemampuan berpikir tingkat tinggi yang dikembangkan dinyatakan sangat valid dengan nilai 91.66\%. Komponen penilaian segi bahasa berkaitan dalam hal kekomunikatifan dan kejelasan butir soal yang dipertanyakan (Munadi, 2011). Persentase nilai yang diperoleh ini menunjukkan instrumen penilaian kemampuan berpikir tingkat tinggi telah menggunakan bahasa sesuai dengan kaidah Bahasa Indonesia, menggunakan bahasa yang komunikatif sesuai valid (Depdiknas, 2017).

Hasil validasi dalam aspek kemampuan berpikir tingkat tinggi pada instrumen penilaian yang dikembangkan bernilai $85.00 \%$. Purwanto (2009), perolehan nilai $85,00 \%$ pada instrumen ini telah tergolong valid. Hasil keseluruhan yang didapat dari validator pada segi kemampuan berpikir tingkat tinggi yaitu sudah valid. Instrumen penilaian yang dikembangkan oleh peneliti sudah bisa dijadikan sebagai instrumen yang dapat mengaktifkan kemampuan berpikir tingkat tinggi peserta didik.

Komponen penilaian validitas oleh validator pada aspek materi, kontruksi, bahasa, dan kemampuan berpikir tingkat tinggi, diperoleh yang paling tinggi nilai validitasnya ialah pada aspek bahasa. Hal ini berarti instrumen penilaian kemampuan berpikir tingkat tinggi materi sistem respirasi ini telah menggunakan bahasa yang jelas, komunikatif dan sesuai kaidah Bahasa Indonesia yang baik. Menurut Sofiyah dkk (2015), setiap butir soal menggunakan bahasa yang jelas, mudah dipahami, dan menggunakan bahasa yang sesuai dengan ejaan yang disempurnakan. Dari ke empat aspek, aspek kemampuan berpikir tingkat tinggi dinyatakan valid, namun penilaian oleh validator lebih rendah dari aspek 
lainnya. Aspek kemampuan berpikir tingkat tinggi ini berarti butir soal dapat mengukur kemampuan menganalisis, mengevaluasi, dan mencipta (Sofiyah dkk, 2015).

Secara keseluruhan, instrumen penilaian kemampuan berpikir tingkat tinggi pada materi sistem respirasi untuk peserta didik SMA/MA Kelas XI berupa soal pilihan ganda dengan rata-rata persentase nilai $87.91 \%$. Purwanto (2009), hasil rata-rata persentase tersebut memperoleh kriteria valid menurut validitas logis dari segi validitas. Hal ini menandakan bahwa instrumen penilaian kemampuan berpikir tingkat tinggi ini dapat digunakan dalam penilaian biologi khususnya materi sistem respirasi.

\section{SIMPULAN}

Proses pengembangan instrumen penilaian kemampuan berpikir tingkat tinggi pada materi sistem respirasi untuk peserta didik SMA/MA kelas XI menggunakan model pengembangan 4-D. Tahapan dalam model ini adalah tahap pendenifisian (define), perancangan (design) dan pengembangan (develop). Pada tahap develop dilaksanakan uji validitas dengan hasil untuk segi materi bernilai $86.11 \%$ dengan kriteria valid, dari segi kontruksi bernilai $88.88 \%$ dengan kriteria valid, dari segi bahasa bernilai $91.66 \%$ dengan kriteria sangat valid, dan segi kemampuan berpikir tingkat tinggi bernilai $85.00 \%$ dengan kriteria valid.

\section{DAFTAR PUSTAKA}

Amin, D.I., \& Darsono, S. (2018). Instrumen Asesmen Pemahaman Konseptual Berorientasi Higher Order Thinking Skills Keterampilan Proses dan Sikap terhadap Sains pada Bahan Kajian Hidrokarbon dan Minyak Bumi. Jurnal Pendidikan, 3(9), 1142-1146.

Arikunto, S. (2016). Dasar-dasar Evaluasi Pendidikan Edisi 2. Jakarta: Bumi Aksara.

Ariningrum, W. (2016). Aspek Materi, Konstruksi, dan Bahasa pada Soal Sastra Ujian Nasional Tingkat SMK Mata Pelajaran Bahasa Indonesia Tahun 2014/2015. Naskah Publikasi. Surakarta: Universitas Muhammadiyah Surakarta.

Arti, E.P.N., \& Hariyatmi. (2015). Kemampuan Guru Mata Pelajaran Biologi dalam Pembuatan Soal HOT (Higher Order Thinking) di SMA Negeri 1 Wonosari Klaten. Seminar Nasional XII Pendidikan Biologi. Solo: FKIP UNS.

Berk, L.E. (2006). Child Development 7/e. Boston: Allyn and Bacon.

Depdiknas. (2008). Panduan Penulisan Butir Soal. Jakarta: Direktorat Pembinaan SMA Ditjen Pendidikan Dasar dan Menengah. 
Depdiknas. (2017). Panduan Penilaian oleh Pendidik dan Satuan Pendidikan untuk Sekolah Menengah Atas. Jakarta: Direktorat Pembinaan SMA Ditjen Pendidikan Dasar dan Menengah.

Erfienti, L., Istiyono, E., \& Kuswanto, H. (2019). Developing lup instrument test to measure higher order thinking skills (HOTS) Bloomian for Senior High School Students. International Journal of Educational Research Review, 4(3), 320-329.

Febriyanto, B., Yuyun, D.H., \& Oom, K. (2018). Peningkatan Pemahaman Konsep Matematis melalui Penggunaan Media Kantong Bergambar Pada Materi Perkalian Bilangan di Kelas II Sekolah Dasar. Jurnal Cakrawala Pendas, 4(2), 32-44.

Forehand, M. (2011). Bloom's Taxonomy- Emerging Perspectives on Learning, Teaching and Technology, http:// projects. coe. uga. edu/ epltt/ index. php? Title $=$ Bloom\%27s_Taxonomy. Diakses 27 Juni 2019, 16.25 WIB.

Gonibala, A., Pikoli, M., \& Kilo, A.L. (2019). Validitas Perangkat Pembelajaran Materi Ikatan Kimia Berbasil Model Pembelajaran Pemaknaan Untuk Melatihkan Sensitivitas Moral Siswa SMA. Jambura Journal of Educational Chemistry. 1(1), $1-6$.

Hadi, S., \& Novaliyosi. (2019). TIMSS Indonesia (Trends in International Mathematics and Sciece Study). Prosiding Seminar Nasional \& Call for Papers, ISBN: 978-6029250-39-8. Di akses 17 Desember 2019 dari http://jurnal.unsil.ac.id/ index.php/sncp/article/view/1096\&ved.

Hamdi, S., Suganda, I.A., \& Hayati, N. (2018). Developing Higher-Rrder Thinking Skill (HOTS) Test Instrument using Lombok Local Cultures as Contexts for Junior Secondary School Mathematics. Research and Evaluation in Education, 4(2), 126135.

Haryanto. (2018). Instrumen Penilaian Kemampuan Berpikir Tingkat Tinggi pada Materi Fungi untuk Peserta Didik SMA Kelas X. Skripsi. Jurusan Biologi Fmipa UNP.

Herlanti, Y. (2015). Analisis Domain Pengetahuan dan Kognitif pada Kurikulum Indonesia Tahun 1984-2013 Mata Pelajaran Biologi Sekolah Menengah Atas, Seminar Nasional XII. Solo: Pendidikan Biologi FKIP UNS.

Ipin, A. (2018). Pengembangan Soal-Soal Pilihan Ganda untuk Mengukur Kemampuan Berpikir Kritis Siswa pada Konsep Sistem Regulasi Manusia untuk Jenjng SMA. Jurnal Mangifera Edu, 3(1), 26-39.

Kadir, A. (2015). Menyusun dan Menganalisis Tes Hasil Belajar. Jurnal Al-Ta'dib, 8(2), $70-81$.

Karim, F.A., dan Marzita, P. (2019). The Development of Higher Order Thinking Skills (HOTS) Assesment Instrument for Word Problems. International Journal of Academic Research in Business and Social Sciences, 9(6), 1079-1083. 
Kodriana, W., Edi, H.M., Akhmad, N. (2017). Pengembangan Soal Tes Berbasis Hots pada Outdoor Learning di Sekolah Dasar. Jurnal Ilmiah Pendidikan Guru Sekolah Dasar, 4(1), 61-72.

Krathwohl, D.R. (2002). A Revision of Bloom's Taxonomy: an overview - Theory intro practice, College of Education, The Ohio State University Pohl, 41(4), 213-218.

Kunandar. (2015). Penilaian Autentik (Penilaian Hasil Belajar Peserta Didik berdasarkan Kurikulum 2013). Jakarta: PT Raja Grafindo Persada.

Kurniawan, G. E. (2018). Pengembangan Modul Pembelajaran Berbasis Model Problem Solving Untuk Meningkatkan High Order Thinking Skill pada Pelajaran IPA Pokok Bahasan Fluida Pelajaran IPAPokok Bahasan Fluida Statis Siswa Kelas VIII SMPN 7 Cirebon. Jurnal Mangifera Edu, 3(1), 62-71.

Kusuma, M.D., Rosidin, U., Abdurrahman., \& Suyatna, A. (2017). The Development of Higher Order Thinking Skill (HOTS) Instrument Assesment In Physics Study. Journal of Research \& Method in Education, 7(1), 26-32.

Marhamah. (2019). Upaya Meningkatkan Kompetensi Guru Kelas dalam Penulisan Soal Pilihan Ganda Berbasis HOTS melalui Pendampingan Semester Tahun Pelajaran 2018/2019 di SD Negeri 47 Cakranegara. JISIP, 3(1), 87-97.

Munadi, S. (2011). Analisis Validasi Kualitas Soal Tes Hasil Belajar pada Pelaksanaan Program Pembelajaran. Cakrawala Pendidikan, Th. XXX, No. 1: 145-159.

Purwanto, N. (2009). Prinsip-Prinsip dan Teknik Evaluasi Pengajaran. Bandung: Remaja Rosdakarya.

Rahmawati. (2016). Seminar Hasil TIMMS 2015. Diakses 15 April 2019 dari http://puspendik.kemendikbud.go.id/seminar/upload/Rahmawati-Seminar-HailTIMSS-2015.pdf.

Ramdiah, S., Abidinsyah., Royani, M., \& Husamah. (2019). Understanding, Planning, and Implementation of HOTS by Senior High School Biology Teachers in Banjarmasin-Indonesia. International Journal of Instruction, 12(1), 425-440.

Rochmad. (2012). Desain Model Pengembangan Perangkat Pembelajaran Matematika. Jurnal Kreano, 3(1), 59-72.

Rofiah, E., Aminah, N.S., \& Ekawati, E.Y. (2013). Penyusunan Instrumen Tes Kemampuan Berpikir Tingkat Tinggi Fisika pada Siswa SMP. Jurnal Pendidikan Fisika, 1(2), 17-22.

Samritin \& Suryanto. (2016). Developing an Assesment Instrument of Junior High School Students Higher Order Thinking Skills in Mathematics. Research and Evaluation in Education, 2(1), 92-107. 
Sofiyah, S., Susanto., \& Setiawani, S. (2015). Pengembangan Paket Tes Kemampuan Berpikir Tingkat Tinggi Matematika berdasarkan Revisi Taksonomi Bloom pada Siswa Kelas V SD. Artikel Ilmiah Mahasiswa, 1(1), 1-7.

Sulistryoni, A.K., Pujayanto., \& Ekawati, E.Y. (2013). Analisis Pencapaian Kompetensi Kognitif Tingkatan Aplikasi (C3) dan Analisis (C4) dalam Pembelajaran Fisika pada Siswa Kelas XI SMA Program RSBI. Jurnal Pendidikan Fisika, 1(1), 19-26.

Susanty, F.D. (2016). Analsis Validasi Soal Tes Hasil Belajar pada Pelaksanaan Pembelajaran Bahasa Arab di Pusat Pengembangan Bahasa (P3B) UIN Suska Riau. Jurnal Penelitian Sosial Keagamaan, 19(2), 112-132.

Susiatin. (2019). Meningkatkan Kemampuan Guru dalam Menyusun Kisi-Kisi Soal dengan Metode Pendampingan Pola "OCF”. Jurnal Dinamika Manajemen Pendidikan. 4(1), 17-24.

Zainab, S., \& Wilujeng, I. (2016). Pengembangan Instrumen Penilaian Tes Objektif Pilihan Ganda untuk Mengukur Penguasaan Materi Ajar Gerak Lurus dan Keterampilan Proses Sains Siswa SMA. Jurnal Pendidikan Fisika, 5(2), 106-113.

Zehlia, A., Luzyawati, L., \& Hamidah, I. (2019). Analisis Pertanyaan Uji Kompetensi pada Buku Biologi SMA/MA Kelas XII Penerbit Erlangga. Gema Wiralodra, 10(2), 165178. 